\title{
Penerapan Model Pembelajaran Snowball Throwing dengan Metode Analisis-Sintesis Untuk Meningkatkan Hasil Belajar IPA Fisika pada Siswa Kelas VIII SMP Negeri 7 Palu
}

\author{
Siti Masyita, Muhammad Ali, dan Kamaluddin \\ smasyita@ymail.com \\ Program Studi Pendidikan Fisika FKIP Universitas Tadulako \\ Jl. Soekarno Hatta Km. 9 Kampus Bumi Tadulako Tondo Palu - Sulawesi Tengah
}

\begin{abstract}
Abstrak -Penelitian ini dilakukan dengan tujuan meningkatkan hasil belajar IPA fisika melalui penerapan model pembelajaran snowball throwing dengan metode analisis-sintesis pada siswa kelas VIII SMPNegeri7 Palu. Jenis penelitian ini adalah penelitian tindakan kelas yang dilakukan dalam 2 siklus, masing-masing siklu sterdiri dari 4 tahap, yakni perencanaan, pelaksanaan observasi dan refleksi. Setiap siklus dilakukan 2 kali pertemuan. Subyek penelitian ini adalah siswa kelas VIII D SMPN 7 Palu dengan jumlah siswa 22 orang. Pada siklus I diperoleh nilai rata-rata 72,7 , presetase ketuntasan klasikal yaitu $68,18 \%$ dan presentase daya serap klasikal $72,72 \%$. Hasil ini belum memenuhi indikator kinerja yang ditentukan sehingga dilanjutkan pada siklus II. Pada siklus II nilai rata-rata yang diperoleh sebesar 80,4 dengan presentase ketuntasan belajar klasikal yaitu $86,36 \%$ dan presentase daya serap klasikal yaitu $80,45 \%$ hal ini sudah memenuhi indikator yang telah ditentukan sehingga dapat disimpulkan bahwa penerapan model pembelajaran snowball throwing dengan metode analisis-sintesis dapat meningkatkan hasil belajar IPA Fisika pada siswa kelas VIII SMPN 7 Palu.
\end{abstract}

Kata Kunci: Model Pembelajaran Snowball Throwing, Metode Analisis-sintesis, Hasil Belajar IPAFisika.

\section{PENDAHULUAN}

Meningkatkan mutu pendidikan banyak hal yang perlu diperbaiki, sehingga perbaikan mutu pendidikan tidak terlepas dari kegiatan belajar mengajar di kelas. Suasana kelas yang kondusif ditandai dengan adanya keterlibatan aktif yang terjadi antara siswa dan guru, terciptanya suasana belajar yang menyenangkan, terbuka dan tanpa ada rasa takut serta tekanantekanan yang dilakukan guru terhadap siswanya.

Menciptakan suasana kelas yang kondusif merupakan tugas utama seorang guru agar dapat menarik minat dan perhatian siswa dalam mengikuti proses pembelajaran. Dalam mewujudkan hal tersebut guru dituntut untuk mampu berinovatif dalam memilih model dan metode pembelajaran yang tepat untuk digunakan.

Berdasarkan hasil observasi pada guru mata pelajaran IPA fisika kelas VIII SMP Negeri 7 Palu terlihat bahwa model pembelajaran yangditerapkan oleh guru di sekolah masih berpusat pada guru (teacher center).

$\mathrm{Hal}$ ini sesuai dengan informasi yang diperoleh dari hasil wawancara pada salah seorang guru mata pelajaran IPA Fisika kelas VIII di SMP Negeri 7 Palu, yang menyatakan bahwa sebagian besar siswa mengalami kesulitan belajar, khususnya pada mata pelajaran Fisika.

Dampak yang ditimbulkan dari hal tersebut terlihat pada hasil belajar siswa, khususnya untuk kelas VIII SMP Negeri 7 Palu pada tahun ajaran 2015-2016 dapat dilihat pada Tabel 1

TABEL 1 HASIL BELAJAR IPA FISIKA SISWA TAHUN

\begin{tabular}{|c|c|c|}
\hline \multicolumn{3}{|c|}{ PELAJARAN $2015 / 2016$} \\
\hline No. & Kelas & $\begin{array}{c}\text { Nilai Rata-rata Semester } \\
\text { Ganjil }\end{array}$ \\
\hline 1. & $\mathrm{VIII}_{\mathrm{A}}$ & 56,78 \\
\hline 2. & $\mathrm{VIII}_{\mathrm{B}}$ & 57,42 \\
\hline 3. & $\mathrm{VIII}_{\mathrm{C}}$ & 63,18 \\
\hline 4. & $\mathrm{VIII}_{\mathrm{D}}$ & 66,71 \\
\hline 5. & $\mathrm{VIII}_{\mathrm{E}}$ & 65,28 \\
\hline
\end{tabular}

Berdasarkan tabel di atas terlihat nilai ratarata akhir semester siswa untuk ke lima kelas belum mencapai standar ketuntasan yang ditetapkan oleh sekolah yaitu 75, yang artinya hasil belajar siswa untuk mata pelajaran IPA fisika itu sendiri masih rendah. Nilai rata-rata semester yang paling rendah diperoleh siswa kelas VIII $_{A}$ sedangkan untuk nilai tertinggi diperoleh kelas VIII .

Berdasarkan permasalahan yang diuraikan di atas, maka peneliti berpandangan bahwa rendahnya hasil belajar yang diperoleh siswa 
disebabkan oleh kurangnya perhatian siswa dalam memperhatikan materi pembelajaran yang disampaikan guru sehingga, perlu adanya perubahan strategi pembelajaran dengan cara menggunakan model pembelajaran.

Pada penelitian sebelumnya yang dilakukan mengungkapkan bahwa hasil belajar siswa yang diterapkan model pembelajaran snowball throwing lebih tinggi dibandingkan siswa yang menggunakan model pembelajaran langsung [1].

$\begin{array}{cccr}\text { Penelitian } & \text { yang } & \text { dilakukan } & \text { tentang } \\ \text { embelajaran } & \text { analitik } & \text { sintetik } & \text { untuk }\end{array}$ meningkatkan kemampuan berfikir kritis dan kreatif matematik siswa SMA mengungkapkan bahwa kemampuan berfikir kreatif dan kritis matematik siswa yang mendapat Pembelajaran Analitik Sintetik Intervensi Divergen (PASID) dan yang mendapat Pembelajaran Analitik Sintetik Intervensi Konvergen (PASIK) secara signifikan lebih baik dibandingkan dengan siswa yang mendapat Pembelajaran Konvensional $(\mathrm{PK})[2]$.

\section{METODE PENELITIAN}

Penelitian ini merupakan penelitian tindakan kelas. Desain penelitian ini mengacu pada model Kemmis dan MC. Taggart [5] yang terdiri dari empat fase yaitu: (1) perencanaan, (2) pelaksanaan tindakan, (3) observasi, (4) refleksi.

Penelitian ini dilakukan di SMP Negeri 7 Palu, kelas yang dijadikan penelitian adalah kelas VIII D yang mengikuti mata pelajaran IPA Fisika semester genap 2016/2017.

Jenis data penelitian ini adalah data kualitatif dan kuantitatif. Teknik pengumpulan data dalam penelitian ini yaitu pemberian tes, observasi dan wawancara.

\section{HASIL DAN PEMBAHASAN}

\section{A. Pra Tindakan}

Sebelum melakukan tindakan siklus I dan II, peneliti melakukan kegiatan observasi awal di SMP Negeri 7 Palu. Peneliti melakukan observasi di kelas VIIID SMP Negeri 7 Palu, yang dijadikan sebagai subyek penelitian. Pada tahap ini untuk mengetahui kemampuan siswa terhadap materi fisika yang telah diajarkan, peneliti memberikan tes awal pada tanggal 27Februari 2017. Tes awal yang diberikan berupa tes pilihan ganda yang berjumlah 10 soal. Kegiatan selanjutnya peneliti membentuk kelompok kooperatif yang heterogen dimana kelompok tersebut terbentuk dari hasil tes awal. Selanjutnya peneliti akan melaksanakan tindakan pembelajaran sesuai sekenario pembelajaran yang akan diterapkan pada siswa kelas VIII $D$ yaitu dengan model pembelajaran snowball throwing.

\section{B. Pelaksanaan Tindakan Siklus I}

Penelitian tindakan siklus I ini dilakukan dari tanggal 06 Maret 2017 Sampai tanggal 13 Maret 2017. Penelitian ini dilakukan 2 kali pertemuan untuk kegiatan belajar mengajar (KBM) dan satu kali pertemuan untuk tes akhir tindakan.

Selama proses pembelajaran berlangsung dilakukan observasi aktivitas guru dan siswa. Untuk hasil observasi terhadap aktivitas guru dalam pembelajaran pada tindakan siklus I terdiri dari 2 kali pertemuan. Observasi aktivitas guru didasarkan pada intisari kegiatan yang tertuang dalam skenario pembelajaran dengan menggunakan model pembelajaran snowball throwing. Skor rata-rata persentase aktivitas guru sebesar $78,00 \%$ atau berada dalam kategori baik.

Observasi aktivitas siswa dilakukan untuk melihat keaktifan siswa dalam mengikuti proses pembelajaran. Persentase keaktifan siswa pada siklus I adalah sebesar 70,55\%. Hal ini berarti taraf keaktifan siswa dalam melakukan proses pembelajaran di kelas tergolong berkategori cukup.

Penilaian afektif siswa diperoleh nilai ratarata sebesar 79,28 dengan kategori baik sedangkan penilaian psikomotor siswa diperoleh nilai rata-rata sebesar 66,20 dengan kategori cukup. Setelah selasai melaksanakan kegiatan pembelajaran siklus I maka kegiatan selanjutnya adalah pemberian tes akhir pada tanggal 17 Maret 2017, bentuk tes yang diberikan berupa tes pilihan ganda sebanya 10 butir, hasil analisis tes hasil belajar dapat dilihat secara singkat dapat dilihat pada table 2

\begin{tabular}{llc}
\multicolumn{3}{c}{ TABEL 2. ANALISIS TES AKHIR TINDAKAN SIKLUS I } \\
\hline No. & \multicolumn{1}{c}{ Aspek yang dinilai } & Hasil \\
\hline 1 & Skor Tertinggi & $15(1$ orang $)$ \\
2 & Skor Terendah & $7(1$ orang $)$ \\
3 & Skor Rata-Rata Siswa & 72,70 \\
4 & Banyaknya Siswa yang Belum & 7 orang \\
& tuntas \\
5 & Banyaknya Siswa yang tuntas & 15 orang \\
6 & Persentase ketuntasan & $68,18 \%$ \\
& klasikal & \\
7 & Persentase daya serap & $72,70 \%$ \\
& klasikal & \\
\hline
\end{tabular}

Dari data Table 3.1 terlihat bahwa jumlah siswa yang tuntas sebanyak 15 orang dan yang belum tuntas sebanyak 7 orang siswa. Untuk persentase ketuntasan klasikal pada siklus I diperoleh $68,18 \%$ dan persentase daya serap klasikal diperoleh $72,70 \%$. Dari hasil persentase 
ketuntasan klasikal tersebut dapat diketahui bahwa setelah diterapkan model pembelajaran snowball throwing terdapat peningkatan hasil belajar siswa, salah satu penyebabnya karena ketika diterapkan model pembelajaran snowball throwing waktu yang digunakan siswa untuk belajar lebih banyak dan sebagian siswa memanfaatkan waktu tersebut dengan baik, dalam hal ini sebagian siswa serius belajar dan berdiskusi dengan teman-temannya, tidak bermain dengan teman-teman kelompoknya saja, akan tetapi hasil ini belum mancapai indikator standar ketuntasan klasikal yang ditetapkan yaitu $80 \%$.

\section{Pelaksanaan Tindakan Siklus II}

Berdasarkan hasil yang diperoleh pada siklus I belum memenuhi indikator kinerja yang telah ditetapkan, maka dilakukan siklus II. Perencanaan pelaksanaan siklus II didasarkan pada hasil refleksi siklus I dengan dilaksanakannya sebanyak 2 kali pertemuan untuk kegiatan belajar mengajar (KBM) dan 1 kali pertemuan untuk tes akhir siklus.

Observasi aktivitas guru dalam pembelajaran pada tindakan siklus II terdiri dari 2 kali pertemuan. Analisis didasarkan pada intisari kegiatan yang tertuang dalam skenario pembelajaran dengan menggunakan model pembelajaran snowball throwing. skor rata-rata persentase aktivitas guru sebesar $90,50 \%$ atau berada dalam kategori Sangat Baik. Hal ini menunjukan bahwa ada peningkatan aktivitas guru pada semua aspek kegiatan.

Hasil observasi aktivitas siswa persentase keaktifan siswa pada siklus II adalah sebesar $90,55 \%$. Hal ini berarti taraf keaktifan siswa dalam melakukan proses pembelajaran di kelas tergolong berkategori sangat baik.

\begin{tabular}{llc}
\multicolumn{3}{c}{ TABEL 3 ANALISIS TES AKHIR TINDAKAN SIKLUS I } \\
\hline No. & Aspek yang dinilai & Hasil \\
\hline 1 & Skor Tertinggi & $19(4$ orang $)$ \\
2 & Skor Terendah & $3(2$ orang $)$ \\
3 & Nilai Rata-Rata Siswa & 80,45 \\
4 & Banyaknya Siswa yang Belum & 3 orang \\
& tuntas & \\
5 & Banyaknya Siswa yang tuntas & 19 orang \\
6 & $\begin{array}{l}\text { Persentase ketuntasan } \\
\text { klasikal }\end{array}$ & $86,36 \%$ \\
7 & $\begin{array}{l}\text { Persentase daya serap } \\
\text { klasikal }\end{array}$ \\
\end{tabular}

Penilaian afektif siswa diperoleh nilai ratarata sebesar 87,87 dengan kategori sangat baik sedangkan penilaian psikomotor siswa diperoleh nilai rata-rata sebesar 74,80 dengan kategori cukup. Setelah selasai melaksanakan kegiatan pembelajaran siklus II maka kegiatan selanjutnya adalah pemberian tes akhir pada tanggal 28 Maret 2017, bentuk tes yang diberikan berupa tes pilihan ganda sebanya 10 butir, hasil analisis tes hasil belajar dapat dilihat secara singkat dapat dilihat pada table 3 .

Dari data tabel 3, terlihat persentase ketuntasan klasikal pada siklus II yaitu sebesar $86,36 \%$ dan persentase daya serap klasikal sebesar $80,40 \%$. Hal ini menunjukkan bahwa hasil pada siklus II telah memenuhi indikator kinerja yang telah ditetapkan.

Berdasarkan hasil analisis terhadap aktivitas guru dan siswa pada siklus I dan siklus II, dapat dilihat bahwa aktivitas guru dan siswa selama mengikuti proses pembelajaran siklus I dan siklus II menurut pengamat sudah cukup baik.

Pada siklus I, rata-rata persentase aktivitas siswa sebesar $78.00 \%$ berada pada kategori baik dan presentase aktivitas guru sebesar $70,55 \%$ berada pada kategori cukup. Pada siklus II rata-rata persentase aktivitas siswa sebesar $90,5 \%$ berada pada kategori sangat baik dan guru sebesar $90,55 \%$ berada pada kategori sangat baik. Jadi dapat disimpulkan bahwa aktivitas siswa dan guru pada siklus I mengalami peningkatan pada siklus II. Ini disebabkan karena kekurangan-kekurangan pada siklus I dapat diminimalisir dan diperbaiki pada siklus II.

Rendahnya persentase ketuntasan klasikal pada siklus I disebabkan karena penyampaian materi yang diberikan masih belum dapat dipahami dengan baik oleh siswa. Sehingga pada siklus I, masih ada siswa yang belum dapat mengerjakan dengan baik soal-soal yang diberikan khususnya dalam mengerjakan tes dalam bentuk pemahaman konsep. Hal ini disebabkan siswa tersebut cenderung diam (tidak bertanya) saat materi yang kurang dipahaminya saat KBM berlangsung, sehingga kesulitan dalam menyelesaikan soal, tidak memperlihatkan dengan baik materi yang disampaiakan, serta tidak belajar untuk persiapan ujian. Selain itu dikarenakan siswa tidak menyelesaikan dengan baik tugas yang diberikan oleh guru.

Hasil yang diperoleh pada siklus II lebih baik dari siklus I, dimana siklus II diperoleh ketuntasan belajar klasikal sebesar $86,36 \%$ dan daya serap klasikal sebesar $80,04 \%$ hal ini sudah memenuhi indikator keberhasilan yaitu sebesar $80 \%$.

Penelitian sebelumnya menunjukkan bahwa dengan menerapkan model pembelajaran snowball throwing dapat meningkatkan hasil belajar siswa dan melatih siswa dalam hal mengemukakan pertanyaan, namun penelitian itu belum memperhatikan kesesuaian metode dengan model yang digunakan sehingga, perlu di tunjang dengan metode yang membiasakan 
siswa pada menyelesaikan permasalahan yang diajukan guru sehingga siswa akan terbiasa dalam hal membuat pertanyaan[3].

Berdasarkan uraian diatas, dapat dikatakan bahwa model pembelajaran snowball throwing dengan metode analisis-sintesisdapat memberikan pengalaman bermakna kepada siswa, sehingga dapat meningkatkan hasil belajar fisika siswa kelas VIII D SMP Negeri 7 Palu.

\section{KESIMPULAN DAN SARAN}

Berdasarkan hasil analisis penelitian
tindakan kelas dapat disimpulkan bahwa
penerapan model pembelajaran snowball
throwing dengan menggunakan metode
analisis-sintesis dapat meningkatkan hasil

belajar IPA Fisika pada siswa kelas VIII D SMP Negeri 7 Palu. Berdasarkan hasil yang diperoleh pada siklus II telah sesuai dengan indikator yang telah ditetapkan.

\section{DAFTAR PUSTAKA}

[1] Inggrina, O.S. (2014). "Pengaruh Model Pembelajaran Kooperatif tipe Snowball Throwing Terhadap Hasil Belajar Siswa Kelas X SMK Tirtayasa Kota Gorontalo". Jurnal Pendidikan Matematika Universitas Negeri Gorontalo.

[2] Mulyana, T. (2008). Pembelajaran analaitik sintetik untuk meningkatkan kemampuan berpikir kritis dan kreatif matematik siswa Sekolah Menengah Atas. Disertasi Universitas Pendidikan Indonesia: Tidak diterbitkan

[3] Kadek. A.S, I Nengah, S \& Siti, Z. (2014). "Pengaruh model pembelajaran snowball throwing berbantuan media konkret terhadap hasil belajar kelas $\mathrm{V} S \mathrm{SD}$ Gugus I Gusti Ngurahrai". E-Journal mimbar PGSD Universitas Ganesha. 2, 6-10 